\title{
Fibrinogen polymorphisms are not associated with the risk of myocardial infarction
}

\author{
C. J. M. Doggen, ${ }^{1}$ R. M. Bertina ${ }^{2}$ V. Manger Cats ${ }^{3}$ and F. R. Rosendahl ${ }^{1},{ }^{2}{ }^{1}$ Department of Clinical \\ Epidemiology, Leiden University Medical Centre, ${ }^{2}$ Haemostasis and Thrombosis Research Centre, \\ Leiden University Medical Centre, and ${ }^{3}$ Department of Cardiology, Leiden University Medical Centre, The Netherlands
}

Received 6 March 2000; accepted for publication 18 May 2000

\begin{abstract}
Summary. In the Study of Myocardial Infarctions Leiden, we investigated the prevalence of three polymorphisms in the $\alpha$ and $\beta$-fibrinogen genes among 560 patients with a myocardial infarction and 646 control subjects. Secondly, we studied the relationships between these polymorphisms and fibrinogen activity and antigen levels. The TaqI, HaeIII and $B c$ lI polymorphisms in the fibrinogen gene were not associated with myocardial infarction. As we found an association of the rare $\mathrm{B} 2$ allele with fibrinogen levels and a
\end{abstract}

similar, but weak, effect for the rare $\mathrm{H} 2$ allele, we conclude that a genetic propensity to high fibrinogen levels does not affect the risk of myocardial infarction. This is evidence against a causal role for fibrinogen levels in the aetiology of myocardial infarction.

Keywords: fibrinogen, myocardial infarction, polymorphisms, aetiology.
Fibrinogen has been shown to be an independent predictor of myocardial infarction. However, whether fibrinogen is a causal risk factor or is elevated as a result of either existing atherosclerosis or the presence of other cardiovascular risk factors remains unclear. Atherosclerosis is nearly always present before the development of myocardial infarction. It could well be that fibrinogen levels are elevated as an acutephase reaction in the presence of atherosclerosis. A similar situation may exist with the presence of cardiovascular risk factors. For example, smoking is associated with increased fibrinogen levels and is simultaneously a risk factor for myocardial infarction. As a result, fibrinogen levels may appear to be associated with myocardial infarction but are, in fact, elevated as a consequence of smoking.

We studied the relationship between fibrinogen and myocardial infarction indirectly. Several polymorphisms in the genes encoding for the three separate chains of fibrinogen have been described. In some studies, these genotypes were associated with high levels of fibrinogen. When these genotypes are associated with higher levels, one would expect these genotypes to be present more often in patients who had a myocardial infarction, but only if fibrinogen plays a causal role in the development of myocardial infarction. In this paper, we present the results

Correspondence: Prof. Dr F. R. Rosendaal, Department of Clinical Epidemiology, Bldg 1 C()-P, Leiden University Medical Centre, PO Box 9600, 2300 RC Leiden, The Netherlands. E-mail: P.R.Rosendaal@lumc.nl of the population-based case-control Study of Myocardial Infarctions Leiden (SMILE) with respect to the relationship between the TaqI polymorphism in the $\alpha$-fibrinogen gene, the HaeIII $(-455 \mathrm{G} / \mathrm{A})$ and BclI polymorphisms in the $\beta$ fibrinogen gene and myocardial infarction among 560 men with a first myocardial infarction and 646 control subjects. Secondly, fibrinogen levels were measured in the latter, and an association with the presence of certain alleles was looked for.

\section{METHODS}

Patients were men below the age of 70 years with a first myocardial infarction. Controls were also men, frequency matched to the patients in 10-year age groups, who had undergone an orthopaedic intervention and had received prophylactic anticoagulants for a short period after this intervention. They did not have a history of myocardial infarction and had not used anticoagulants for at least 6 months before participation in this study. Both patients and controls were born in the Netherlands. Full details of the SMILE study have been published elsewhere (Doggen et al, 1998).

Morning fasting blood samples were drawn from the antecubital vein into two Sarstedt Monovette tubes containing $0.106 \mathrm{~mol} / \mathrm{l}$ trisodium citrate. We separated the blood sample into cells and plasma by centrifugation for $10 \mathrm{~min}$ at $3000 \mathrm{~g}$ at room temperature. Genomic DNA was extracted 


\section{C. J. M. Doggen et al}

from the white blood cells by a salting-out method (Miller et al, 1988) The TaqI, HaeIII and BclI polymorphisms were genotyped after amplification of relevant DNA regions by polymerase chain reaction (PCR) and digestion with the appropriate restriction enzymes as described previously (Thomas et al, 1991, 1995) Common alleles are coded as $\mathrm{H} 1, \mathrm{~T} 1$ and $\mathrm{B} 1$, and the rare alleles are indicated as $\mathrm{H} 2 \mathrm{~T} 2$ and B2 In the control subjects, fibrmogen activity was measured in plasma using the Clauss thrombin time method on a fully automatic coagulometer STA (Diagnostica Stago, Boehringer Mannheim) Fibrunogen antigen levels were measured with an enzyme-linked immunosorbent assay (ELISA)

Allele frequencies in patients and control subjects were compared by chl-square analysis A chl-square test was used to compare the observed numbers of each genotype with those expected for a population in Hardy-Wemberg equilibrium An odds ratio (OR) with a 95\% confidence interval $(95 \% \mathrm{CI})$ was calculated as a measure of relative risk Allele frequencies and means of fibrinogen are presented with the $95 \%$ CI Analysis of variance was used to compare differences between means

\section{RESULTS}

The frequencies of the common alleles, the TaqI, HaeIII and $B C I$ polymorphısms, were 071,079 and 083 , respectively, with no difference between patients and control subjects (Table I) The distribution of genotypes was as expected for a population in Hardy-Wemberg equilibrium For persons carrying the $\mathrm{T} 2$ allele of the TaqI polymorphism, the risk of myocardial infarction was not increased, with odds ratios at or close to unity, netther was the risk of myocardial infarction increased for carriers of the $\mathrm{H} 2$ allele of the HaeIII polymorphism, nor for carriers of the B2 allele of the BclI polymorphism
Among control subjects, carriers of the T2 allele of the TaqI polymorphism had simılar fibronogen activity and antigen levels compared with homozygous carriers of the common allele (Table II) Frbrinogen levels appeared to be higher for heterozygous and homozygous carriers of the $\mathrm{H} 2$ allele of the HaeIII polymorphism, although not significantly Anigen levels were higher for carruers of the rare allele of the BcII polymorphism compared with non-carriers, and a trend towards higher activity levels appeared as well

\section{DISCUSSION}

Possession of rare alleles of the TaqI polymoiphism in the $\alpha$ fibrmogen gene and the HaeIII and BcII polymorphusms in the $\beta$-fibrinogen gene was not a risk factor for myocardial infarction Neither homozygous nor heterozygous carriers of rare alleles showed an increased or decreased risk compared with homozygous carriers of common alleles As we observed higher fibrinogen levels for carrieıs of the B2 allele of the BcII polymorphism, these data do not support a causal role for fibrmogen in the aetology of myocardial infarction

Our results are in agreement with those of the Etude CasTemoins sur l'Infarctus du Myocarde (ECTIM) study, in which genotype frequencies of the HaeIII and BclI polymorphisms were also simular in patients with a myocardial infarction and in control subjects (Scarabin et al 1993, Behague et al, 1996) Homozygous carriers of the rare allele of the TaqI polymorphism were less frequent among patıents In Ireland, but not in France (Behague et al, 1996) The frequency of the rare allele of the HaeIII polymorphism was virtually identical in patients with a myocardial infarction and in control subjects from Sweden (Green et al, 1993), in an elderly population (van der Bom et al, 1998), in individuals who underwent coronary angiography (Gaidemann et al, 1997) and in men with and without ischaemic

Table I. Trequencies of the common alleles of TaqI HaeII and BcII polymorphisms among 560 patients and 646 control subjects and the risk of myocardial infarction for heterozygous and homozygous can ners of the rare alleles

\begin{tabular}{|c|c|c|c|}
\hline Genotype of & $\begin{array}{l}\text { Patients } \\
\text { Number }(\%)\end{array}$ & $\begin{array}{l}\text { Control subjects } \\
\text { Number }(\%)\end{array}$ & Odds ratio $(95 \% \mathrm{Cl})$ \\
\hline \multicolumn{4}{|l|}{ TaqI polymorphısm } \\
\hline $\mathrm{T} 1 \mathrm{~T} 1$ & $286\left(\begin{array}{ll}51 & 1\end{array}\right)$ & $327(506)$ & 1 \\
\hline $\mathrm{T} 1 \mathrm{~T} 2$ & $228(407)$ & $265(410)$ & $10(08-13)$ \\
\hline $\mathrm{T} 2 \mathrm{~T} 2$ & $46(82)$ & $54(84)$ & $10(06-15)$ \\
\hline Allele frequency $\mathrm{T} 1$ & 071 (CI 0 69-0 74) & 071 (CI 0 69-0 74) & \\
\hline \multicolumn{4}{|l|}{ HaeIII polymorphısm } \\
\hline $\mathrm{H} 1 \mathrm{H1}$ & $343(613)$ & $404(625)$ & 1 \\
\hline $\mathrm{H} 1 \mathrm{H} 2$ & $199(355)$ & $211(327)$ & $11(09-14)$ \\
\hline $\mathrm{H} 2 \mathrm{H} 2$ & $18(32)$ & $31(48)$ & $07(04-12)$ \\
\hline Allele frequency H1 & 079 (Cl $077-081)$ & 079 (CI 0 77-0 81) & \\
\hline \multicolumn{4}{|l|}{ BcII polymorphism } \\
\hline B1B1 & $378(675)$ & $444(687)$ & 1 \\
\hline B1B2 & $168(300)$ & $179(277)$ & $11(09-14)$ \\
\hline B2B2 & $14(25)$ & $23(36)$ & $07(04-14)$ \\
\hline Allele frequency B1 & $083($ CI $080-0$ 85) & $083(\mathrm{CI} O 81-0$ 85) & \\
\hline
\end{tabular}


Table II Tibrmogen activity and antigen levels in 646 control subjects accordng to the genotypes of the different polymorphisms

\begin{tabular}{|c|c|c|c|c|c|}
\hline \multirow[b]{2}{*}{ Genotype of } & \multirow[b]{2}{*}{ Numbel } & \multicolumn{2}{|c|}{ Fibrinogen acilvily $(\mathrm{g} / \mathrm{l})$} & \multicolumn{2}{|c|}{ Fibrmogen antigen $(\mathrm{g} / \mathrm{l})$} \\
\hline & & Mean $(\mathrm{CI})$ & P value* & Mean (CI) & P value* \\
\hline \multicolumn{6}{|c|}{ TaqI polymorphism } \\
\hline$\Gamma 1 \Gamma 1$ & 327 & $326(319-333)$ & & $276(268-283)$ & \\
\hline $\mathrm{T} 1 \mathrm{~T} 2$ & 265 & $327\left(\begin{array}{llll}3 & 18-3 & 36\end{array}\right)$ & & $273(264-281)$ & \\
\hline $\mathrm{T} 2 \mathrm{~T} 2$ & 54 & $316(298-333)$ & 05 & $270(254-286)$ & 08 \\
\hline \multicolumn{6}{|c|}{ HaeIII polymorphısm } \\
\hline $\mathrm{H} 1 \mathrm{H1}$ & 404 & $322(316-329)$ & & $270(263-276)$ & \\
\hline $\mathrm{H} 1 \mathrm{H} 2$ & 211 & $331(321-340)$ & & $282(272-291)$ & \\
\hline $\mathrm{H} 2 \mathrm{H} 2$ & 31 & $332(303-361)$ & 03 & $282(252-312)$ & 01 \\
\hline \multicolumn{6}{|c|}{ Bcll polymorphism } \\
\hline $\mathrm{B} 1 \mathrm{~B} 1$ & 444 & $322(316-328)$ & & $269(263-275)$ & \\
\hline B1B2 & 179 & $334(323-344)$ & & $285(275-296)$ & \\
\hline $\mathrm{B} 2 \mathrm{~B} 2$ & 23 & $330(293-367)$ & 01 & $279(240-318)$ & 003 \\
\hline Overall & 646 & $325(320-331)$ & & $274(269-279)$ & \\
\hline
\end{tabular}

*P-value of analysis of variance compaing levels between the three differ ent genotypes

heart disease (Tybjærg-Hansen et al, 1997) To our knowledge, only one study, which included Italıan patients with familial myocardial infarction, found an increased risk for carriers of the rare allele of the BcII polymorphism (Zito et al, 1997) Given the study size of 560 patients and 646 control subjects, we would have been able to detect a significant excess ( $P$-value $<005$ ) of allele carriess in patients vs control subjects of about $8 \%(80 \%$ power $)$, i e relative risks as low as 15 Thus our results, which show no association between polymorphisms and myocardial infarction, are not caused by lack of power

The frequency of the common allele of the TaqI polymorphism of $071 \mathrm{~m}$ our control subjects was similar to frequencies in healthy individuals from the UK, Ireland, France and Finland, which range from 072 to 075 (Humphries et al, 1987 Thomas et al, 1995, Behague et al, 1996. Rauramaa et al, 1997) The same was true for the frequency of 079 of the common allele of the HaeIII polymorphism Frequencies ranging from 075 to 081 have been described (Thomas et al, 1991, Green et al, 1993, Scarabin et al, 1993, Behague et al, 1996, Gardemann et al, 1997. Tybjærg-Hansen et al, 1997 Maıgaglıone et al, 1998, van der Bom et al, 1998, van't Hooft et al, 1999) Again the fiequency of the BcII polymorphism of $083 \mathrm{~m}$ our control subjects was simular to that of other healthy populations in which the frequency ranged fiom 083 to 085 (Thomds et al, 1995, Behague et al, 1996, Rauı amaa et al, 1997, Zito et al 1997)

No association existed between the TaqI polymorphism and fibrmogen levels, either in our study or in other studies (Humphries et al, 1987, Connor et al, 1992, Rauramaa et al, 1997) A trend towards increasmg fibrmogen levels with the rare allele of the HaeII polymorphusm $(-455 \mathrm{~A})$ was found (Thomas et al, 1991, Green et al, 1993, Tybjærg-Hansen et al, 1997. Gardemann et al, 1997, van der Bom et al, 1998, van't Hooft et al, 1999), although the association was not always significant (Connor et al, 1992, Margaglione et al,
1998), as in oul own study Again, the rane allele of the BcII polymorphism seemed to be associdted with increasing fibrinogen levels in some studies (Humphies et al, 1987, Zito et al, 1997), but not all (Connor et al, 1992, Rauramaa et al, 1997) We found that heterozygous carriers had the highest fibımogen activity level although the association was only sıgnificant for the fibrinogen antigen level, not the activity level Altogether, this suggests that there probably is a weak relationship between the rare variants in the $\beta$ fibronogen gene and fibronogen levels

We conclude that the TaqI, HaeIII and BcII polymorphisms in the fibrunogen gene are not related to myocardial infarction As we found an association of the B2 allele of the $B c$ II polymorphism with fibrunogen levels and a similar but weak, effect for the $\mathrm{H} 2$ allele, we conclude that a genetıc pı opensity to high fibrinogen levels does not affect the risk of myocardial infarction This is evidence against a causal role for fibrinogen levels in the aetiology of myocardial infarction

\section{ACKNOWLEDGMENTS}

This research was supported by The Nethellands Heart Foundation (grant no 92345 ) The authors wish to thank the cardiologists of the Departments of Caldiology, Leiden University Medical Centre and Diaconessenhuis Leiden and Dr F J M van der Meer, Head of the Leiden Anticoagulant Clunic for their kind co-operation We thank Mrs T Visser for peiforming the laboratoly measurements, and Mrs J J Schreijer for secietarial support of the Study of Myocardial 1nfarctions Leiden We wish to acknowledge Dr H L Vos for his useful comments on this papel

\section{REFERENCES}

Behague I Porres O Nicaud V Evans A Aıveler D Luc G Cambou J Scarabin P Bara L Green $\Gamma$ \& Cambien $\Gamma$ (1996) 
$\beta$ Fibrmogen gene polymorphisms are associated with plasma fibrinogen and coronary artery disease in patients with myocardial infarction The ECTIM study Crrculation, 93, 440-449

Connor, J M, Fowkes, FG R , Wood, J, Smith, FB, Donnan, PT \& Lowe, GDO (1992) Genetıc variation at fibrinogen loci and plasma fibrmogen levels Journal of Medical Genetrs, 29, 480482

Doggen, C J M , Manger Cats, V, Bertina, R M \& Rosendaal, FR (1998) Interaction of coagulatıon defects and cardıovascular risk factors increased risk of myocardial infarction associated with factor V Leiden or prothrombin 20210A Circulation, 97, 10371041

Gardemann, A, Schwartz, O, Haberbosch, W, Kat7, N, Welß, T, Tillmanns, H, Hehrleın, $\Gamma W$, Waas, W \& Eberbach, A (1997) Positive association of the $\beta$ fibrinogen $\mathrm{H} 1 / \mathrm{H} 2$ gene val iation to basal fibrmogen levels and to the increase in fibrmogen concentration during acute phase reaction but not to coronary artery disease and myocardial infarction Thrombosis and Haemostasis $77,1120-1126$

Green F, Hamsten, A, Blomback, M \& Humphries, S (1993) The role of $\beta$-fibrinogen genotype in determinmg plasma fibrinogen levels in young survivors of myocardial infarction and healthy controls from Sweden Thrombosis and Haemostasis, 70 915-920

Humphries, S E, Cook, M Dubowitz, M, Stırlıng Y \& Meade, TW (1987) Role of genetic varration at the fibrmogen locus in determination of plasma fibrinogen concentrations Lancet, I $1452-1455$

Margaglione, M , Cappucci, G, Colarzzo, D, Pirro, L, Vecchione, G , Grandone, E. \& Di Minno, G (1998) Frbrinogen plasma levels in an apparently healthy general populdtion - relatron to environmental and genetic determmants Thrombosis and Haemostasis, 80, 805-810

Miller, S A , Dykes, D D \& Polesky, H F (1988) A simple saltmg out procedure for extracting DNA from human nucleated cells Nucleic Acıds Research, 16, 1215

Rauı amaa, R, Vassanen, S, Nissinen, A, Rankınen, T, Penttıla, I, Saarıkoskı, S, Tuomilehto, J, Gagnon, J, Perusse, L \& Bouchard, C (1997) Physical dctıvity, fibrmogen plasma level and gene polymorphisms in postmenopausal women Thrombosis and Haemosiasts, 78, 840-844

Scarabm, P, Bara, L, Ricard, S., Poirler, O, Cambou, J, Arveler D, Luc G, Evans, A E, Samama, M M \& Cambien, $\Gamma$ (1993) Genetic variation dt the $\beta$-fibrinogen locus in relation to plasma fibrmogen concentrations and risk of myocardial infarction The ECTIM study Arteriosclerosis and Thrombosis, 13, 886-891

Thomas, A E Green, $\Gamma \mathrm{R}$, Kelleher, C H, Wilkes, H C, Brennan, PJ, Mcade TW \& Humphries, SE (1991) Varlation in the promoter region of the $\beta$ fibrinogen gene is associated with plasma fibrinogen levels in smokers and non-smokers Thrombosis and Haemostasis, 65, 487-490

Thomas, A E, Green, $\Gamma \mathrm{R}$, Lamlum, H \& Humphries, S E (1995) The association of combmed $\alpha$ and $\beta$ fibrinogen genotype on plasma fibrinogen levels in smokers and non-smokers Journal of Medical Genetics, 32, 585-589

Tybjærg-Hansen, A . Agerholm-Larsen, B, Humphries, S L, Abildgaard S, Schnohr, P \& Nordestgaard, B G (1997) A common mutation $(\mathrm{G}-455 \rightarrow \mathrm{A})$ in the $\beta$-fibrmogen promoter is an independent predictor of plasma fibrinogen, but not of ischemic heart disease A study of 9127 individuals based on The Copenhagen City Heart Study Journal of Clmical Investigation, 99, 3034-3039

van der Bom, JG de Madt, M PM, Bots, ML, Haverkate, F, de Jong, PT.VM, Hofman, A, Kluft, C \& Grobbee, DE (1998) Elevated plasma fibrinogen Cause or consequence of caldiovascular disease? Arteriosclerosis Thrombosts, and Vascular Biology, $18 \quad 621-625$

van't Hooft, FM, von Bahr, S JF, Silverra A, Iliadou, A, Eriksson, P \& Hamsten, A (1999) Two common, functional polymorph1sms in the promoter region of the $\beta$-fibrmogen gene contribute to regulation of plasma fibrinogen concentration Aitei iosclerosis, Thrombosis, and Vascular Brology. 19, 3063-3070

Zito, $\Gamma$, Di Castelnuovo, A , Amore, C. D'Orazıo, A , Donatı, M B \& Iacovello, $L$ (1997) Bcll polymorphism in the fibrinogen $\beta$-cham gene is associated with the risk of familial myocardial infarction by increasing plasma fibrinogen levels A case-control study in a sample of GISSI-2 patients Arteriosclerosis, Thrombosis, and Vascular Blology, 17, 3489-3494 